\title{
Arte, brincadeira e transfiguração: análise de uma produção singular
}

\section{Art, game and transformation: a singular production analysis}

\author{
Nathany Andrea Wagenheimer Belmaia'; Marta Dantas²
}

\section{Resumo}

As manifestações artísticas que comumente vemos são advindas de técnicas que vêm sendo transmitidas há centenas de anos. São poucos os que se esforçam por fazer algo inovador. Aqueles que se aventuram em uma criação original, podem encontrar dificuldade de aceitação de sua obra, ou, quando não raro, permanecer no anonimato. Este artigo visa a apresentar o resultado da pesquisa vinculada ao projeto "Infames, casos de singularidade histórica". Esse projeto teve como intuito procurar produções singulares, dar espaço e voz a sujeitos que muitas vezes se quer tornam-se conhecidos. Em um trabalho de campo realizado em Londrina-PR, encontramos a obra de Douglas, que aqui foi analisada. Ele é um garoto que com quinze anos desenvolveu seu próprio método para fazer miniaturas tridimensionais em papel alumínio.

Palavras-chave: Brinquedo. Brinquedo artesanal. Arte bruta. Arte Naïf. Transfiguração.

\begin{abstract}
The artistic manifestations we see these days come from techniques that have been passed along through centuries. There are few people who make an effort to do something new. Those who venture in making something original may find the acceptance of their art difficult, or remain anonymous. This article aims to present the result of the research connected to the project "Infamous ones: cases of historical singularity". The purpose of this project was to look for and analyze singular productions, giving space and voice to people that rarely become famous. Through a field work carried out in Londrina-PR, Douglas's work was found and analyzed. He is a fifteen-year-old boy who developed his own method of making threedimensional miniatures in aluminum foil.
\end{abstract}

Key words: Toy. Handmade toy. Rough art. Art Naïf. Transformation.

\footnotetext{
${ }^{1}$ Bacharel em Ciências Sociais pela UEL.

${ }^{2}$ Mestre em História e Doutora em Sociologia pela UNESP, coordenadora do curso de especialização "História e Teorias da Arte: Modernidade e Pós-Modernidade", docente de História da Arte do Departamento de Arte Visual da UEL e do Pprograma de Mestrado em Letras da UEL.
}

Semina: Ciências Sociais e Humanas, Londrina, v. 27, n. 1, p. 77-89, jan./jun. 2006 
Esperamos que a criação artística seja original, singular, criativa. Entretanto, na sociedade contemporânea, a arte também pode ser atingida pelos efeitos da massificação. O conceito de criação, artística ou não, advém da mesma raiz do conceito de criatividade. Por conseguinte, os significados de ambos tornam-se intrínsecos.

De acordo com Houaiss (2004, p.311), "criativo", do latim creatus, é aquele que tem força criadora, provido de criatividade, que se distingue pela aptidão para criar. É um inventor, um inovador. Criatividade, por extensão, seria uma característica daquele que é criativo, provido de inventibilidade, inteligência e talentos (natos ou adquiridos) para criar, inventar ou inovar em diferentes aspectos ou áreas.

Ainda de acordo com Houaiss (2004), "criar", do latim creare, é a ação humana de conceber, inventar, dar existência ao que não existe; ou, então, aperfeiçoar algo já existente, dar a algo uma nova forma ou um novo uso. Criar é tudo aquilo que é fruto do trabalho ou do talento humano e produto de sua ação criadora.

O que liga a "criação" à "criatividade" é a inovação e a invenção. Criação pressupõe algum tipo de invenção ou inovação, e essas últimas pressupõem algum tipo de criatividade, que pode ser expressa através de uma produção artesanal, artística, esportiva, intelectual etc.

Pessoas realmente criativas, tal como as entendemos aqui, são minoria, casos de exceção. Esses seres, muitas vezes, passam pela terra anônimos e desaparecem da mesma forma que surgem, sem deixar rastros. Justamente por esse motivo é que aqui tivemos por finalidade procurar essas pessoas, conhecê-las e estudá-las, para dar voz e espaço a produções e criações singulares e deixar um registro dessas manifestações para a história.

Se tomássemos o significado da palavra criação ao pé da letra, seria quase um contra-senso, ou uma redundância, falar em "criações singulares". Porém, dado que nem toda criação é, de fato, absolutamente uma inovação, é que decidiu-se denominar o tipo de produção que estávamos em busca: as "criações singulares".

Nesta pesquisa ${ }^{1}$, desenvolvida durante o período de um ano e meio, deparamo-nos com alguns sujeitos interessantes, com algumas atividades curiosas, porém, apenas um deles revelou-se importante, de acordo com os nossos objetivos, que eram os de localizar produções realmente singulares. Nesse artigo, gostaríamos de apresentar Douglas Aparecido, um garoto que, com apenas quinze anos, constrói com papel alumínio, um mundo em miniatura.

Tal como a criação, a análise da mesma também foi pouco convencional. Tentamos demonstrar que uma abordagem que utiliza outras disciplinas, além da própria teoria da e história da arte, não só é possível como é enriquecedora.

\section{Brincando se cria!}

O primeiro impulso para que Douglas começasse a criar foi dado pelo desenvolvimento natural de seu lado lúdico, pois foi brincando que a produção de seus objetos começou. Brincar é algo natural ao homem. $\mathrm{E}$, quando criança, isso se manifesta espontaneamente.

"Existem registros de brinquedos infantis, provenientes de diversas culturas, que remontam a épocas pré-históricas, demonstrando assim que é natural ao homem brincar, independente de sua origem e de seu tempo." (WEISS, 1989, p.20).

De origem muito humilde e sem condições para ter acesso a brinquedos caros, teve uma idéia, aos doze anos, de inventar um meio de contornar essa situação. Começou a produzir seus próprios brinquedos.

A mãe do menino trazia-lhe, diariamente, para o almoço, um marmitex (ou "quentinha" como é conhecida em algumas regiões), pois trabalhava e não tinha tempo para cozinhar para Douglas e os outros filhos. Depois de comer a comida, restava aquele recipiente de alumínio. Foi então que surgiu a idéia de aproveitar esse material.

Em dada ocasião, Douglas e o irmão resolveram encher de água o tanque de lavar roupas de sua casa, pegaram aquele recipiente que restou do marmitex e 
fizeram patinhos para brincar na água do tanque. $\mathrm{O}$ primeiro passo estava dado, e de patinhos, Douglas passou a fazer outros bichinhos, casinhas e pessoas, desenvolvendo cada vez mais sua habilidade de lidar com aquele material (o papel alumínio) e criar coisas com ele.

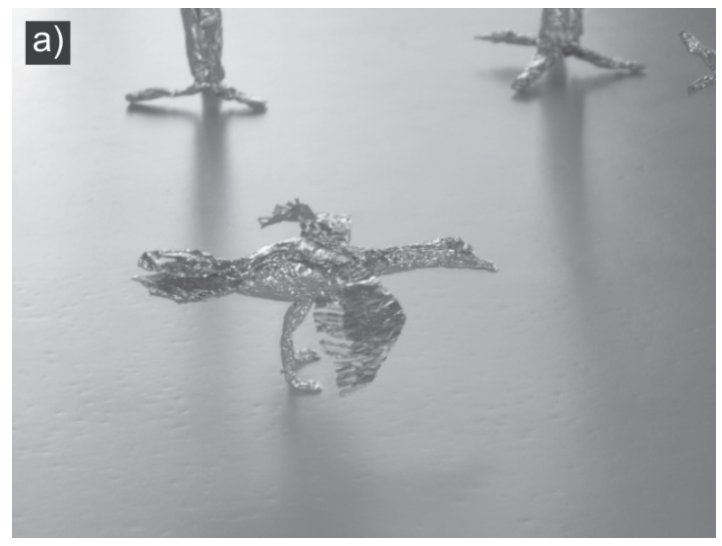

Figura 1.
A maior parte das miniaturas produzidas por Douglas são uma representação do universo do qual ele faz parte. Ele reproduz, em miniatura, o que vê em seu cotidiano, que são animais, pessoas simples, plantas etc., como nas figuras abaixo.

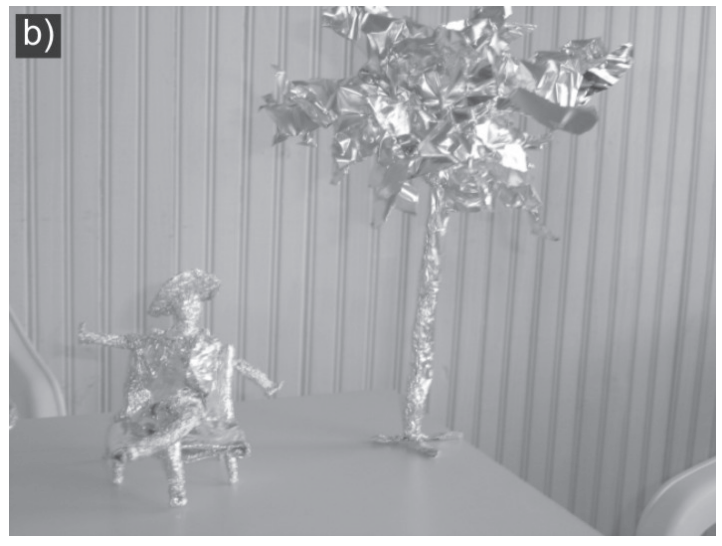

Fotos de produções de Douglas. a) Ave. - b) Camponês sentado ao lado de uma árvore.

Esses objetos de papel alumínio, que ele criava, tornaram-se os brinquedos com os quais se divertia. No universo infantil, brinquedo não é só aquele que foi produzido especialmente com a finalidade de criança brincar, como bonecas, carrinhos etc. Tudo pode se tornar brinquedo: uma vassoura pode virar um garboso cavalo ou um lápis pode ser facilmente convertido num trenzinho, por exemplo. Para soltar a imaginação e se divertir, qualquer coisa pode se tornar um brinquedo, mesmo que não o seja de fato, como uma vassoura, cuja finalidade é limpar, e não servir de cavalinho.

Assim, Douglas construía, em miniatura, todo um mundo de sonho e fantasia que servia para suprir uma carência, que era a impossibilidade de adquirir a brinquedos novos e caros. O brilho do alumínio, no caso de Douglas, vem para encantar um universo desencantado, marcado pela pobreza e pela falta de recursos para aquisição de bens materiais. Nos brinquedos que ele criava com aquele material de segunda mão, encontrava uma forma de conhecer o mundo, explorá-lo, recriá-lo, exercitar as fantasias e liberar os diferentes desejos que se manifestavam. Ele tinha, em suas mãos, um mundo só dele, repleto de seus sonhos e vontades, mundo, até mesmo, com outros significados que ele próprio atribuía a cada nova construção e desconstrução.

Os brinquedos hoje são comprados prontos e acabados. O único trabalho da criança é brincar. Então, "simplesmente perante esse universo de objetos fiéis e complicados, a criança só pode assumir o papel de proprietário, de utente, e nunca de criador; ela não inventa o mundo, utiliza-o: os adultos preparamlhe gestos sem aventura, sem espanto e sem alegria." Barthes (apud WEISS,1989, p.27).

Hoje, ao comprar um brinquedo na loja, ele já vem com todo um rol de funções do que pode ser feito com ele. A criança não precisa mais imaginar. Os brinquedos funcionam quase automaticamente. Alguns brinquedos, como o carrinho de controle remoto, por exemplo, marcam a instauração de um novo tipo de gesto, o passivo. É só apertar o botão e observar.

Com o tempo e as mudanças nas relações de sociabilidade, o brinquedo também passou por várias transformações. Apesar do percurso histórico da produção de brinquedos estar intimamente ligado e, até confundir-se com a história da produção de 
miniaturas, esses dois termos não foram e nem são hoje a mesma coisa.

Desde meados do século XV, têm-se relatos, em toda Europa, das famosas miniaturas de madeira feitas por artesãos de Nurembergue. Essas miniaturas eram reproduções de objetos pessoais, livros, pertences ou móveis das casas das pessoas em escala bastante reduzida. Os museus, sobretudo os alemães e suíços, possuem ainda hoje um amplo conjunto de reproduções miniaturizadas de casas, interiores e objetos de algumas famílias.

No século XVIII, a demanda por pequenos objetos para decoração ou pequenos objetos para crianças tornou-se muito maior e, por isso, os artesãos tinham de trocar as obras grandiosas pela produção de coisas minúsculas. Assim, a representação, em forma reduzida, de coisas e pessoas da vida cotidiana resultou num artesanato popular que era destinado, tanto à satisfação dos adultos, como das crianças, e que servia tanto para o acervo de colecionadores e relicários e objetos de decoração, quanto para brinquedo para as crianças. Mas "com efeito, na segunda metade do século XIX, quando começa a acentuada decadência dessas coisas, percebe-se que os brinquedos tornam-se maiores, vão perdendo aos poucos o elemento discreto, minúsculo e agradável." Benjamin (apud WEIS, 1989, p.21).

Não se sabe precisar ao certo se as miniaturas começaram a ser feitas para as crianças e, posteriormente, os adultos apoderaram-se delas, ou se o caminho foi inverso, ou, ainda, se a miniatura penetrou no cotidiano infantil e adulto ao mesmo tempo. Mas o fato é que hoje a produção de brinquedos não é mais artesanal, mas industrial.

$\mathrm{O}$ brinquedo mudou. Mudou junto com o tempo. A partir do século passado, com a Revolução Industrial, ocorre uma grande ruptura: o brinquedo deixa de ser aquela peça artesanal, minuciosa, passando a ser produzido em escala, para atender à demanda cada vez maior dos centros urbanos em expansão. (WEISS, 1989, p.21).
Antes de surgirem as grandes indústrias que comercializam os brinquedos, eles eram feitos por artesãos, que foram construindo, através do tempo, um saber, um know how com técnicas que foram sendo desenvolvidas e passadas de geração para geração. Um dos ramos desse saber deu origem ao que hoje se conhece como brinquedo artesanal.

Pode-se pensar que o que Douglas produz pode ser considerado brinquedo artesanal por ser uma produção caseira e manual. Apesar de ter algumas características semelhantes, isso não é verdade, pois o brinquedo artesanal vem de todo um saber acumulado e de técnicas que são ensinadas. O que ele faz também é diferente do brinquedo industrializado por máquinas, num processo em que cada operário só faz uma parte do trabalho. O brinquedo artesanal é todo feito por uma só pessoa que detém todas as técnicas desse fazer, e elas são passadas de geração para geração.

A produção de Douglas torna-se singular, à medida em que ele mesmo desenvolve as técnicas de como lidar com o papel alumínio, um material incomum para confecção de brinquedos ou miniaturas. Isso é um fator importante, pois o mais comum na produção artesanal seria utilizar madeira, panos, papéis e outros materiais mais tradicionais.

A primeira técnica que ele criou foi a de moldar o alumínio somente com as mãos, sem o uso de tesoura, cola ou qualquer outro tipo de instrumento. Com o tempo, ele conseguiu adquirir tão boa precisão, que quando vai cortar o papel alumínio para fazer uma miniatura, já tem, de antemão, noção da quantidade de papel que será necessário para a confecção, de modo que consegue cortar o alumínio em um tamanho quase exato para o que será feito. Quase não se vêem sobras de material quando o trabalho está acabado, aproveitando, assim, o máximo do papel alumínio.

Essas e outras técnicas não foram transmitidas a Douglas por um "mestre": ninguém comunicou a ele o conhecimento acerca deste fazer, ou seja, não foi o herdeiro de uma "experiência". Experiência aqui é entendida no sentido benjaminiano do termo, que resulta de um conhecimento acumulado adquirido e passado de geração para geração, fruto de uma 
tradição viva e coletiva que vincula os indivíduos a um passado comum. Douglas é especial porque não precisou da experiência, somente de suas vivências para descobrir seu modo de criar.

Ainda de acordo com Walter Benjamin, vivência é resultado das atividades cotidianas de um indivíduo isolado em seu trabalho e em sua história individual, não havendo uma aprendizagem de conhecimentos que foram guardados por grupos humanos, é só o indivíduo e sua vida, seus sentimentos e desenvolvimento. Douglas descobriu por si só que poderia se expressar por meio daquele material e desenvolveu suas próprias técnicas para isso.

Com isso, podemos dizer que ele poderá um dia vir a se tornar um tipo parecido com o 'narrador' de Benjamin. Ao fazer suas miniaturas usa olho, mão e alma, característica própria da tradição da narrativa, que pressupõe não somente um narrador contador de histórias, mas um atuante, um homem manipulador e artesão. Mesmo que seu conhecimento não tenha advindo da experiência, ele desenvolveu uma técnica passível de ser ensinada e passada adiante. É um criador.

"Entre os grandes criadores sempre existiram homens implacáveis que operam a partir de uma tabula rasa. Querem uma prancheta: foram construtores." (BENJAMIN, 1994, p.116).

Esses grandes criadores são raros, são exceções hoje. A maior parte de nós têm uma atitude meramente contemplativa diante do mundo. Atuamos como espectadores de um mundo teatro, de um mundo espetáculo, um mundo panorama, exposto à contemplação passiva. A maioria de nós não procura ser participante e atuante no sentido da criação, ou seja, da construção criativa e inovadora. Nossas ações acabam quase sempre uma cópia do que vemos e, assim, ficamos, geralmente, com o papel de reprodutores de uma cultura que busca cada vez mais uma maior homogeneização entre as pessoas.

Para transformar o papel alumínio e dar vida a ele por meio de suas miniaturas, podemos dizer que Douglas potencializou o que Gaston Bachelard (PESSANHA, 1994) conceitua como imaginação criadora. Fazendo uma distinção entre dois tipos de imaginação, designa como imaginação formal a imaginação que é copiadora do real, reprodutora do que vê. Já a imaginação criadora não é subalterna da visão, pois ela não é só espectadora, mas ativa. Essa imaginação apodera-se do que vê, não para copiar e reproduzir, mas para criar algo novo, que solicita uma intervenção ativa e modificadora do homem: do homem artesão, manipulador, criador - tanto na ciência como, e principalmente, na arte.

O estímulo inicial para que a idéia de Douglas pudesse surgir foi um impulso lúdico, uma vontade de brincar com as coisas do mundo e manipulá-las, já que o menino não tinha possibilidade de consumir brinquedos prontos e acabados. Quem saberá dizer o que ocorreria se ele se tivesse tido acesso a esses produtos prontos? Se ele tivesse tido os mais lindos e caros brinquedos não sentiria necessidade de fabricar os próprios e, talvez, suas miniaturas em papel alumínio não existissem hoje.

Algumas pessoas espantam-se que em um meio tão carente possa nascer um trabalho criativo, como é o de Douglas. Ele se apropriou do que tinha à mão para criar, sua vontade de transfigurar sua realidade foi maior do que as adversidades que tivera de enfrentar e acabou inventando uma nova e sua forma de se expressar. Na criação de seus brinquedos, sua vontade ultrapassa as limitações dadas pela carência de recursos.

Na nossa sociedade, mesmo que a maior parte da população seja de origem humilde, os brinquedos mais valorizados são os brinquedos industrializados, comprados prontos. Esse "pré-conceito" de que o industrializado seria melhor que o que é feito em casa não é de hoje. Para tentar entender esse fenômeno, é preciso voltar um pouco na história e retornar até a antiga sociedade grega escravista.

$\mathrm{Na}$ sociedade grega antiga, o trabalho intelectual tinha uma posição preponderante sobre o trabalho manual. As grandes construções teóricas da ciência e da filosofia eram consideradas fruto do "ócio" dos homens livres, e a manualidade era caracterizada como atividade dos subalternos e escravos. A partir 
disso podemos ter uma idéia de onde se dá o início da desvalorização do trabalho manual de que nossa cultura é herdeira.

Essa idéia acaba se disseminando e todo o trabalho manual é abarcado nesse preconceito, por isso, na hora da compra de um brinquedo, os mais procurados são os prontos, industrializados, em que o único "trabalho" gerado é o da criança brincar com ele. Assim, o brinquedo artesanal fica sem espaço na hora da compra. Quanto ao fazer em casa, a questão não é muito diferente.

Muitos pais não incentivam ou se quer admitem que os filhos façam seus próprios brinquedos, porque os elementos que são utilizados na feitura destes, o papel, a terra, a areia, lata, a madeira, a cola, o papel etc., muitas vezes, trazem "sujeira" e "bagunça" para dentro de casa. Essa "sujeira", que é a matéria prima do brinquedo artesanal, subverte o bem estar doméstico e não combina com o ideal higienista da sociedade. E, no ambiente escolar, na maior parte das escolas as matérias de artes não são valorizadas ou levadas a sério por alunos e professores.

Embora sem a aprovação das mães, em geral, é bem comum a criança sentir-se atraída, por exemplo, por destroços que surgem de uma construção, de reformas em casa, no jardim, restos de material da marcenaria, do alfaiate, ou, até mesmo, pelo que seria descartado, como latas, papel, jornais e plásticos usados. Nesses restos que sobram, elas reconhecem o rosto que o mundo das coisas volta para elas.

De acordo com Áries (ARIÉS, 1981, p.88), alguns brinquedos nasceram da atitude das crianças de imitar os adultos, reduzindo o que viam à sua escala: foi o caso, por exemplo, do cavalo de pau, numa época em que o cavalo era o principal meio de locomoção. Mas não só isso. Quando elas se apropriam desses restos, não só imitam as obras dos adultos, como também estabelecem diversas conexões entre os mais diferentes materiais. Cada nova brincadeira, cada nova construção tem um significado diferente, incoerente ou não, que é construído desconstruído pela criança através de suas brincadeiras.
"Com isso as crianças formam seu próprio mundo de coisas, mundo pequeno, inserido num mundo maior". (BENJAMIM, 1984, p.77).

Douglas forma seu pequenino mundo de alumínio. O prazer vai além do fazer, pois cada vez que faz um animal, uma pessoa, uma casinha, ele cria suas histórias, brinca e constrói um mundo encantado de fantasias onde exprime seus desejos. Ele transfigura tanto histórias de seu cotidiano, envolvendo animais e pessoas do seu convívio, como personagens da literatura infantil, por exemplo, a Chapeuzinho Vermelho (vide figura abaixo). Ele é dono desse mundo encantado, e é dando forma que ele atua sobre o mundo real, reconhece-o e o recria para si mesmo.

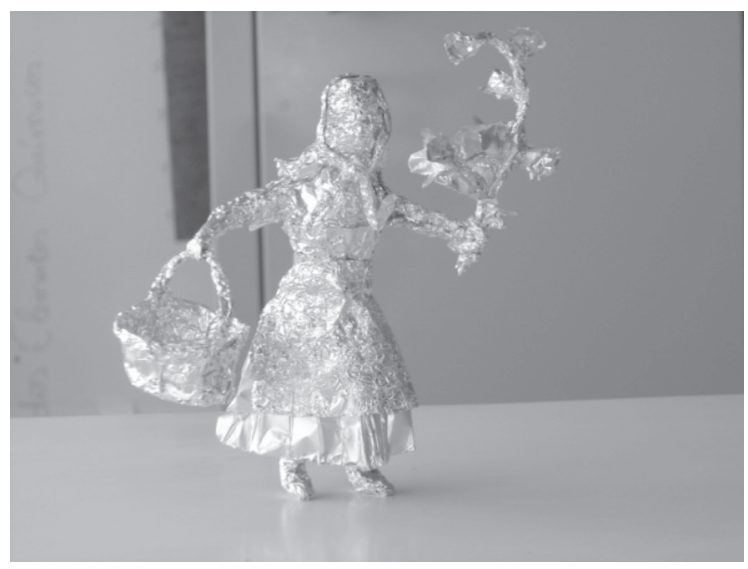

Figura 2. Representação de Douglas da Chapeuzinho Vermelho levando a cesta para a vovó.

Muitas crianças não têm oportunidade de potencializar a experiência lúdica porque já recebem brinquedos prontos ou os pais não permitem que eles criem seus próprios brinquedos. A criança é barrada do contato com o material artesanal, porque ele traz "sujeira e bagunça", e, assim, não tem a possibilidade de poder brincar com os elementos do trabalho manual. Isso gera a morte da produção caseira, de modo que o espaço para produção e consumo desse tipo de brinquedo diminui substancialmente.

Além disso, há a questão da imposição social, que se manifesta até mesmo entre as crianças. De acordo com os padrões, os brinquedos "belos e bonitos" são os comprados industrializados, não o que é feito manualmente. Assim, um carrinho motorizado, com 
controle remoto e buzina torna-se não só mais interessante que um que um carrinho de rolimã, por exemplo, ou uma boneca Barbie, mais atraente do que bonecas pano ou de sabugo. Além disso, possuir ou não esses objetos de valor já faz diferença.

Os valores de grandeza e diferença já nos são passados desde cedo. No nosso sistema, coisas caras e bonitas estão restritas somente àqueles que detém o poder aquisitivo. Com isso, o fato de possuir essas coisas que estão restritas a uma parcela da população que detém o poder, liga a imagem do portador desses objetos a uma camada social mais elevada.

E, dessa forma, possuir esses brinquedos caros gera um tipo de status entre as crianças, status esse que distingue as que detêm ou não poder aquisitivo, e, por isso, a busca pelo industrializado é maior. Brinquedos feitos com materiais baratos e facilmente obtidos (até com sucatas e outros materiais desprezados) tornam-se desinteressantes, pois, além de não terem a mesma beleza, não geram status.

Essa domesticação do nosso modo de agir começa já desde criança. Mais tarde, o símbolo de poder não será o brinquedo caro, mas uma roupa de grife, o carro, uma conta bancária.. O que, às vezes, não se tem em mente, é que o fazer artesanal pode ser tão divertido quanto o brincar, pois além de desenvolver a criatividade e imaginação da criança, pode ser um fator que aproximação entre pais e filhos, um momento que estarem juntos, fazendo um brinquedo.

Numa cultura que procura adestrar as pessoas a consumir produtos acabados, o sujeito acaba ficando com o papel de simples consumidor de bens culturais e demais mercadorias. Transformando e dando nova feição à matéria bruta ou semi-elaborada, Douglas foge à regra e torna-se uma exceção: ultrapassa a condição de um sujeito passivo e imprime sua marca pessoal e intransferível.

\section{Afinal, isso é arte?}

Tentaremos explicar a produção de Douglas por meio de alguns conceitos pertencentes à História da Arte, mas não pretendemos rotulá-la. Pode-se afirmar, com algum risco de simplificação, que seus objetos apresentam algumas características da arte naïve e outras da arte bruta.

A maior parte da obras de arte naïve consistem em pinturas feitas por pessoas que não têm uma formação artística acadêmica, que descendem de camadas humildes da sociedade ou começam pintar numa fase da vida mais tardia da vida, devido ao tempo que nesse momento têm disponível ao veremse liberados do trabalho e das obrigações com a família. A arte naïve também é cultivada com um meio, para satisfazer um desejo de dar vazão à criatividade.

Desde o aparecimento de Henri Rousseau na França, considerado um dos primeiros naïfs modernos, foram dados diversos nomes para esse tipo de manifestação, como Arte Primitiva Moderna ou Pintores de Domingo, mas a denominação mais aceita e que permaneceu foi mesmo a de arte naïve.

A palavra francesa naïve, ou o seu singular masculino naif, vem do latim nativus, que significa nascente, natural, espontâneo, ingênuo e primitivo. Essas duas últimas palavras, que correspondem, no latim, respectivamente à ingenuus, nascido livre, primitivus, o que pertence ao estado primeiro de algo, também podem servir para caracterizar certas obras.

Ao dizer que algo é primitivo, primordial, que apareceu antes de alguma coisa, entende-se, por extensão, a existência de outra coisa posterior ao que se refere primitivo. A arte naïve é assim designada pelo fato de existir em contraste a uma forma "educada" para a criação artística, com moldes já estabelecidos.

Embora a arte popular e a arte naïve apresentem características semelhantes (como o autodidatismo, o uso de técnicas rudimentares adquiridas de forma empírica ou pela observação da execução de uma obra, a liberdade de criação e a ausência de normas formais), elas se distinguem num aspecto fundamental: a arte popular está ligada ao artesanato e às tradições que vão sendo passadas entre gerações.

Os pintores (ou escultores, em alguns casos) de tendência naïve não são profissionais. De acordo com 
Ambrósio (1999), essas obras transmitem ingenuidade e pureza porque cada pessoa desenvolve suas próprias técnicas, cada um descobre sua própria maneira de produzir. Um dos elementos que torna uma obra naïve, única, é o emprego de diferentes técnicas em cada produção, mesmo pertencendo a um mesmo autor.

É comum que esse tipo de produção acabe quase sempre representando o mundo em que o autor se insere e coisas de seu cotidiano. Por isso, quase sempre é possível descobrir as fontes de alguns trabalhos na iconografia popular das ilustrações de velhos livros, nas folhinhas suburbanas, nas imagens de santos ou em algumas paisagens comuns. Assim, não se trata de uma criação totalmente subjetiva, que não tem nenhuma referência da cultura.

Douglas vive em Santa Cecília do Pavão, uma cidadezinha paranaense a cerca de sessenta quilômetros de Londrina. Essa cidade combina o estilo de vida urbano, com comércio, bares e mercados com o rural, tipicamente interiorano. Fruto de uma vivência substancialmente campestre, as miniaturas de Douglas traduzem o universo do menino, que reproduz as formas daquilo que vê, como exemplo, roceiros, cavalos, galinha, entre outros, tal como na arte naïve. Mas o fato é que os objetos de Douglas não só reproduzem as formas daquilo que vê, pois ao brincar e manipular suas miniaturas, ele lhes dá outros significados: uma casinha, por exemplo, já não é mais um abrigo de pessoas, mas um personagem da história.

Mais do que reproduzir seu meio, os artistas naïfs esforçam-se por representar a natureza profunda das coisas sem levar em conta as suas limitações impostas por seu conhecimento. O que não significa que ajam como "artistas amadores", que se esforçam por dominar técnicas e estilos que desconhecem, tentando copiar a obra de grandes mestres, embora esse tipo de criação, pela própria definição, guarde certo grau de "amadorismo". Podemos dizer

que essa arte existe desde que o homem passou a sentir necessidade de se expressar artisticamente, assim, toda arte é naïve em sua origem. Além disso, ela existe na maior parte dos países do mundo e não está 'determinada' por um período histórico o que faz dela um fenômeno único na História da Arte. (DANTAS, 1997, p.91).

O que sabemos é que eles retiram da sua própria solidão os meios para restituir, na imaginação, a idéia que fazem do mundo e deles mesmos. São imagens interiores, extravasadas através de formas plásticas. Este desejo de criar imagens parece, muitas vezes, invadir esses indivíduos de forma perturbadora. (DANTAS, 1997, p.97).

Além da maior parte da obra naïve ser constituída por pinturas, o que distancia Douglas dos naïfs é justamente o que o aproxima da arte bruta: o amadorismo dos naïfs os leva, algumas vezes, ao impulso de copiar ou dominar os modelos e técnicas acadêmicas clássicas. A fronteira conceitual entre a arte naïve e a arte bruta é bem tênue. Ambos os estilos não participam dos circuitos culturais e são feitos por pessoas que, comumente, que não têm nenhuma formação artística.

Douglas cria em seus objetos suas próprias técnicas e meios de expressão. E isso, somado ao fato de que o material com o qual ele trabalha é inusitado (o papel alumínio), aproxima-o mais da arte bruta, na qual a técnica não tenta ser apreendida, mas surge ao acaso, pura e espontânea a partir dos impulsos do autor. Essas produções apresentam certa originalidade, porque sua técnica não advém de uma tradição.

A descoberta das obras brutas teve início em clínicas psiquiátricas suíças e alemãs e é a Jean Dubuffet que se deve o mérito de estudá-las, consagrá-las, cunhando-as de "arte bruta". Normalmente, os autores de arte bruta são pessoas marginais devido a sua condição social, ou ao rótulo de "louco". Segundo Dubuffet, há dois tipos de arte: aquela academicamente correta, culta, e a selvagem, bruta. 
Mas, é apenas em 1945 que o pintor Jean Dubuffet lança a idéia de "arte bruta," qualificando artisticamente (e pela primeira vez) as criações de nãoprofissionais, inclusive e sobretudo dos psiquiatrizados, quer dizer, aqueles que as instituições do mundo moderno denunciaram como "associais e desprovidos de cidadania." Em outras palavras, Dubuffet (1971) passa a problematizar o que chamou de "arte culta," ao privilegiar um tipo de produção marginal, cujos temas, materiais, técnicas e sistemas de figuração apresentam pouca ou nenhuma relação com a tradição ou com tendências da moda, nenhum compromisso com o mercado ou com os destinatários da produção artística; um modo de produção extraído por seus autores do fundo de seu próprio ser e que plasticamente transgride "as imagens do mundo apresentadas pela cultura. (FRAYZE-PEREIRA, 1999, p.48).

A arte bruta deve nascer da insubmissão, das cruezas da vida pessoal diária e das coisas mais humildes. A arte bruta é, de acordo com Dubuffet, uma produção de "arte imediata, sem exercícios, uma arte bruta", que é emanada somente do ser, de seus impulsos e humores do momento. Essa noção contempla uma criação livre de valores morais, convicções, padrões ou estética vigentes. A arte bruta revela a liberdade dos impulsos, independente das informações recebidas pela cultura. De acordo ainda com Dubuffet, toda arte deve ser expressão, o mais livre quanto possível, de interdições morais, costume e razão.

Sendo assim, as obras do acervo de arte bruta seguiam critérios não-convencionais, pois deveriam ser obras que não obedecessem à estética vigente, não sofressem influências da educação social, e questionassem, de certa forma, a própria imposição cultural, pois muitos objetos, tidos comumente como arte, que se vêem sempre em todos os lugares, normalmente estão impregnados de estereótipos e reflexos condicionados pela educação.
A arte bruta priorizava a produção de internados em estabelecimentos psiquiátricos, presidiários, asilados, entre outros, à produção de pessoas tidas como "normais". Dubuffet " [...] pensava que a atividade criativa dos loucos, assim como a dos médiuns, não era totalmente inconsciente, mas uma forma de resistência, um protesto deliberado contra o mundo, a vida e a sociedade baseados numa única forma de conhecimento - o racional. Para ele, essas obras aspiram a uma outra maneira de comunicação e recusam a difusão unilateral de verdades impostas por um único tipo de linguagem baseada na palavra, no verbo, no conceito. Esses homens e mulheres tidos como loucos, médiuns ou "simplesmente" marginais, teriam ultrapassado os limites impostos pela moral e pela sociedade, teriam rompido com elas a partir do momento em que passaram a escutar a voz dos seus desejos, da sua vontade." (DANTAS, 2002a, p.224).

Por esse motivo, a concepção dessa arte trouxe à baila uma discussão com a psiquiatria, que considerava a arte bruta como uma outra designação da "arte patológica”. Essa posição era combatida com fervor por Dubuffet, pois este considerava "[...] conseqüente considerar, sob os mesmos olhos e sem fazer categorias especiais, tanto os trabalhos devidos aos autores reputados sãos como aos reputados doentes." Dubuffet (apud DANTAS, 2002a, p.221).

Em 1951, no texto "Honneur aux valeurs sauvages", Dubuffet declara que é impossível definir as linhas divisoras entre "arte de loucos e de nãoloucos". No fragmento abaixo, faz menção de que há duas formas para resolver esse impasse: ou alargarmos nosso conceito de normalidade, ou classificamos todos os artistas como "doentes":

Não há, verdadeiramente, na maior parte dos casos, nenhum critério que justifique uma discriminação de obras que se poderia considerar sãs e de obras que se poderia considerar patológicas. Creio, sinceramente, que esta discriminação não faz sentido e não responde a nada. Eu não me ressinto da situação a partir da qual a arte cessa de ser sã e começa a incorporar o caráter mórbido e receio que 
esta fronteira entre arte sã e arte patológica desapareça [...]. De fato, os mecanismos psicológicos dos quais procede toda a criação da arte são tais, ao que me parece, que é necessário ou classificá-las, de uma vez por todas, no domínio do patológico, e considerar o artista em todos os casos como psicopata, ou alargar nossa concepção do que seja sanidade e normalidade, e recuar de tal maneira seu limite, que a loucura possa tomar lugar. Dubuffet (apud DANTAS, 2002a, p.222).

Apesar de persistirem aqueles que defendem a arte psicopatológica, a grande contribuição dessa discussão é abrir a possibilidade de colocar em xeque a nossa própria noção de arte, da arte regida pela racionalidade, a arte profissional, culta.

O público tem um "olhar educado" que apenas reconhece como arte aquilo que se estabelece como arte, o que é mostrado nos museus e galerias. Operase com meios de expressão já consolidados, e o diferente pode causar estranhamento ou até mesmo choque:

Quando uma "produção desse gênero" migra de um lugar sinistro como o hospício, onde foi gestada durante anos, para o espaço branco de um museu de arte, onde fica exposta à visitação, o espectador poderá se surpreender com o visível se, por acaso, vier a pensar não apenas naquilo que vê mas, sobretudo, no modo como vê. (FRAYZE-PEREIRA, 1999, p.51).

Por meio da crítica da "arte culta" é que Dubuffet abre a possibilidade desse modo de "manifestação transgressiva' colocar-se ao lado da arte consagrada nos museus e galerias. Com isso, pode-se revisar o próprio modo de ver o mundo, a arte e as limitações que a educação social impõe.

Por ser de um caráter absolutamente individual, a produção de Douglas, de uma forma sutil, subverte a própria imposição do condicionamento cultural, entretanto, não da mesma forma que os artistas brutos, não de maneira tão transgressiva. Ao criar seus objetos, ele não tem a preocupação se aquilo que faz será aprovado ou não por outras pessoas, pois o processo é livre, na medida em que no ato criativo não tem esse tipo de coisa em mente. Quando Douglas faz suas miniaturas, exprime sua marca na obra, pois ela é única, feita por ele, portanto, especial. Todos os pormenores foram feitos por ele e mais ninguém, ao contrário do que ocorre na indústria, onde muitos participam do processo de produção.

Nem todos os artistas ligados a esse tipo de arte são doentes psiquiátricos ou marginais. Douglas poderia ser encaixado na noção de arte bruta se em sua obra se observasse, de fato, a transgressão, que é o elemento fundamental que caracteriza esse tipo de produção.

As miniaturas que Douglas nasceram do impulso lúdico para suprir uma necessidade, que era a de adquirir brinquedos acabados. Suas miniaturas não "transgridem" o social da mesma forma que o artista bruto que, conscientemente, quer subverter, e até negar uma ordem de valores com a sua produção. Os artistas brutos são "rebeldes" e seu modo de expressão transgressivo distancia-se de qualquer forma de reprodução da realidade.

Entretanto, nessas obras, é fundamental que a invenção e os meios de expressá-la sejam originais, o que é o caso de Douglas, que inventa seus meios e técnicas. Com isso, concluímos que as miniaturas de Douglas pertencem tampouco à categoria da arte bruta, quanto à categoria de arte naïve, apesar de, evidentemente, se aproximar de ambas.

O fato de não considerarmos "arte" ou encaixar o que ele faz em alguma categoria artítica não é nenhum demérito. $\mathrm{O}$ importante não é saber se o que ele produz tem ou não valor de obra de arte, mas sim saber que o que produz nasceu uma atividade criadora e tem um potencial transfigurador, pois seus objetos nasceram do mesmo impulso que gera a arte.

\section{A noção de transfiguração através da arte.}

A realidade do garoto não é das mais fáceis: sua vida é humilde, marcada pela escassez e com muitos 
irmãos para dividir um pequeno espaço num casebre. Estuda em um período e no outro trabalha como limpador de covas no cemitério para conseguir um dinheiro extra. A criação de Douglas cumpre um papel de renovação da vida, de transformação. Douglas faz suas miniaturas, cria suas histórias e traz um pouco de magia, encanto e ludicidade à sua vida.

A idéia de transfiguração da existência não é algo novo e, de acordo com Nietzsche (2001) em O Nascimento da Tragédia, já está presente desde os antigos gregos. É para transfigurar os males e os horrores da vida que os gregos criaram os Deuses no Olímpo ou a arte apolínea, tornando a vida possível ou mais desejável. Porém, essa arte, que consiste só na aparência nos engana, pois ela é uma miragem que máscara o sofrimento e as atrocidades da existência.

Se a beleza é uma aparência é porque há uma verdade, que é a essência. Mais ainda: a beleza é uma aparência, um fenômeno, uma representação que tem por objetivo mascarar, encobrir velar a verdade essencial do mundo [...] Produzir a beleza significa se enganar na aparência e ocultar a verdadeira realidade. (MACHADO, 1999, p.18).

Ainda de acordo com Nietzsche (2001) o homem sente na embriaguez da potência dionisíaca uma força que abarca a desmesura e a conciliação com a natureza. Aí ele compreende a ilusão em que se vivia ao criar um mundo de beleza que mascarava a verdadeira realidade. $\mathrm{O}$ problema está no momento que se retorna da "embriaguez" (que é a perda de lucidez) e não se consegue mais suportar o horror da vida, a existência tal como ela se apresenta, por isso, o puro dionisíaco traz o aniquilamento da vida.

A estratégia artística é integrar (é não suprimir) o dionisíaco, transformando o sentimento de desgosto, causado pelo absurdo da vida, em aparência fantasiosa capaz de tornar a vida possível, suportável ou até mesmo desejável. E assim é que, por meio da "arte trágica", torna-se possível a redenção, a transfiguração pela produção artística que possibilita a união da aparência (apolíneo) e da essência do mundo (dionisíaco), que não é mascaramento da dor, mas sim, uma forma de resistência ao sofrimento.

A arte pode trazer a perda de si, um tipo de embriaguês que pode levar ao reencontro com a natureza.

Para Dubuffet, a arte deveria ser a teatralização do desespero, impulso negador da vida, mergulho profundo na escuridão do ser como se este quisesse impedir a ação da vida, anular o tempo. Na dinâmica entre o criar e o mergulhar, como numa festa dionisíaca, vem a embriaguez, a perda de si. É Dioniso, o deus pagão, que se apodera do indivíduo, que o torna desmesurado, que o faz se perder de si mesmo para reconciliá-lo com a natureza. (DANTAS, 2002a, p.226).

De algum modo, Douglas, com suas miniaturas, transfigura a sua realidade. Evidentemente que hoje suas miniaturas não são mais usadas como brinquedo. Mas o papel que elas cumpriam, que era o de preencher algo, não deixa de existir. O prazer está no fazer, no criar, em exprimir ali seus desejos e carências e, com isso, criar um mundo encantado de fantasias, construindo uma realidade diferente da que ele vive, um mundo de sonhos dentro de uma realidade de agruras. Essa atividade deixa sua vida mais branda e enternecida.

Só que, mais do que isso, a produção de Douglas permite-lhe dar um sentido à sua vida. Tudo começou com uma brincadeira e hoje é mais que uma atividade lúdica. Da escassez e das cruezas da vida é que vem a necessidade da criação artística:

A criação artística, para ter seu pleno interesse, necessita de uma concentração que não são compatíveis com a vida social de nossos artistas profissionais. É quando o homem está só, que ele sente forte tédio, que ele não pode contar com nenhuma espécie de distração e nem satisfação vinda do exterior, com alguma espécie de festa, que as condições são mais favoráveis para que nasça nele a necessidade de 
fabricar, por seus próprios meios, completamente só e para seu próprio uso, um teatro de festas e encantamentos. Dubuffet (apud DANTAS, 2002a, p.161).

Isso permite repensar o papel que o padrão social ocupa, determinando nossas ações no sentido do consumo, da passividade, de tornar-nos espectadores e não criadores, ativos e transformadores. Continuamos a reproduzir os valores que nos são passados, mas, muitas vezes, não percebemos que os elementos culturais podem ser re-arranjados e recombinados de forma que apareçam outros tipos de expressão. Douglas encontrou o seu, mas cada um tem em si um potencial criador diferente a ser descoberto.

A atividade lúdica anda de mãos dadas com a atividade criadora, e não é preciso ser artista para se poder transfigurar a realidade. Se essa força criativa que existe em Douglas não sucumbir às exigências alienantes da nossa sociedade, ele poderá sim, vir a ser um artista um dia.

\section{Considerações finais}

A produção de Douglas não é absolutamente inovadora, pois toda a produção de arte bruta apresenta materiais artisticamente não-convencionais. Entretanto, seu processo de criação e as circunstâncias em que ele ocorre tornam sua obra interessante. Podemos considerar assim, se tivermos em conta que por "criativo" não se entende somente uma invenção ou uma obra com total inovação, mas, também, o aperfeiçoamento ou diferentes usos do que já existe.

Douglas cria e se expressa através do papel alumínio, um material que não é comum para a confecção de miniaturas, ademais, desenvolve suas próprias técnicas para produzi-las tridimensionalmente. Isso o torna um inventor, inovador.

Não foi nosso objetivo encaixá-lo em nenhuma categoria artística, embora seja importante ressaltar que sua atividade criadora se aproxima de alguns tipos de arte, como a arte naïve ou a arte bruta. Rotular a atividade de Douglas não é relevante, se considerarmos que o que esperamos da arte é que ela não seja normal, convencional, mas inusitada, imprevista. O importante é esclarecer que o mesmo impulso lúdico que deu origem às suas miniaturas pode dar origem, de fato, à arte.

O importante, de acordo com os objetivos da nossa pesquisa, era encontrar uma produção singular, considerando a obra, o indivíduo e sua história, é considerar essa criação a partir de seu potencial transfigurador.

Foi por meio dessa criação que conseguiu suprir suas carências e necessidades. A princípio, o que o garoto produzia servia para preencher a falta de brinquedos industrializados. Porém, por meio de suas miniaturas, não só conseguia dar vazão à sua imaginação e ao seu impulso lúdico, mas também permitia-se uma espécie de transfiguração. Pode-se dizer que, nesse caso, o momento do ato da criação funciona como uma válvula de escape da realidade, e essa oportunidade advém da possibilidade de penetrar num mundo de fantasias e encantamento, bem diferente daquele enfrentado no dia-a-dia. Isso é o que lhe permite de certa maneira transfigurar o "horror da vida".

O prazer está no fazer, no criar, em exprimir ali seus desejos e construir uma outra realidade, um mundo de sonhos dentro de uma realidade de agruras. Esse "fazer" é mais que um passatempo, pois criando ele enternece e dá sentido à sua vida. A falta e a escassez deixaram um vazio que foi preenchido pela atividade da criação.

Por meio de uma abordagem multidisciplinar, tentamos alcançar o propósito dessa investigação: dar voz a uma criação singular. Por esse tipo de criação ser, quase sempre, relegado à marginalidade e não ser valorizado é que esse trabalho se torna importante. 


\section{Agradecimentos}

Agradecemos à todos os professores, alunos e colaboradores envolvidos no projeto e à Universidade Estadual de Londrina pelo financiamento da pesquisa.

\section{Referências}

AMBRÓSIO, O. Os pincéis de Deus: vida e obra do pintor naïf Waldomiro de Deus. São Paulo: Ed. UNESP, 1999.

ARIÈS, P. História social da criança e da família. Rio de Janeiro: Guanabara Koogan, 1981.

BENJAMIN, W. A criança, o brinquedo, a educação. São Paulo: Summus, 1984.

Magia e técnica, arte e política. Ensaios sobre literatura e história da cultura. São Paulo: Brasiliense, 1994.

DANTAS, M. De olho no passado: a pintura de Ranchinho. 1997. Dissertação (Mestrado) Faculdade de Ciências e Letras da Universidade Paulista, Assis.

. Os filhos de Dioníso: arte e loucura no pensamento de Jean Dubuffet. In: SANTOS, V. E. (Org.). O trágico e seus rastros. Londrina: Eduel, 2002a.
Arthur Bispo do Rosário: a estética do delírio. 2002b. Tese (Doutorado) - Universidade Estadual Paulista - Unesp, Araraquara.

FRAYZE-PEREIRA, J. A. O desvio do olhar: dos asilos aos museus de arte. Psicol. USP, 1999, vol.10, no.2.

HOUAISS, A.; VILLAR, M. S.; FRANCO, F. M. M. Dicionário Houaiss da língua portuguesa. Rio de Janeiro: Objetiva, 2004.

MACHADO, Roberto. Nietzsche e a verdade. São Paulo: Paz e Terra, 1999.

NIETZSCHE, F. O Nascimento da tragédia. São Paulo: Martins Fontes, 2001.

PESSANHA, J. A. Prefácio. In: BACHELARD, G. O direito de sonhar. São Paulo: Difel, 1994.

WEISS, L. Brinquedos \& Engenhocas: atividades lúdicas com sucata. São Paulo: Scipione, 1989. 